\title{
Fungal endophytes of Himalayan Cold Desert Induces Heat tolerance in Rice (Oryza sativa L.)
}

Arpitha P S ( $\sim$ arpithaps909@gmail.com )

University of Agricultural Sciences Bangalore https://orcid.org/0000-0003-3659-5037

Earanna $\mathbf{N}$

University of Agricultural Sciences, Bangalore

Shivashankara K S

IIHR: Indian Institute of Horticultural Research

Laxman R H

IIHR: Indian Institute of Horticultural Research

\section{Research Article}

Keywords: Cold desert, fungal endophytes, Rice and Heat stress

Posted Date: June 14th, 2022

DOI: https://doi.org/10.21203/rs.3.rs-1339767/v3

License: () (1) This work is licensed under a Creative Commons Attribution 4.0 International License. Read Full License 


\section{Abstract}

The plants growing in cold desert of western Himalaya have inhabited diversified endophytes. These endophytes can provide fitness to plant under harsh environmental situations. In the current study, 22 fungal endophytes isolated from Artemisia and Xerophytic plants growing in the cold desert were screened for thermo-tolerance at different temperature ranges $\left(28,3032,34,36,38\right.$ and $\left.40^{\circ} \mathrm{C}\right)$ under in vitro. The only three isolates viz., A2, A7 and X5 exhibited growth up to $40^{\circ} \mathrm{C}$ and identified as Penicilium funiculosum (A2), Ceriporia lacerate (A7) and Endomelanconiopsis endophytica (X5) using ITS region. These endophytes inoculated to rice seedlings and exposed to elevated temperature $\left(45^{\circ} \mathrm{C}\right)$ for $7 \mathrm{hr}$ per day for 10 days to study their effect on tolerance of rice to heat stress. The results revealed that endophytes inoculated seedlings showed sustained improvement in shoot and root growth. The $E$. endophytica was chosen to be the best endophyte to impart heat stress as per Fernandez model. This study suggested that cold desert endophytes could induce heat tolerance in plants.

\section{Introduction}

The global temperature increases day by day due to change in climate. Frequent heat waves have had serious impacts on rice production (Zhang and White, 2021). Historical data analysis envisaged that $7-8 \%$ of rice yield has been decreased due to raise in temperature to $1^{\circ} \mathrm{C}$ (Baker et al., 1992 ). International Rice Research Institute (IRRI) demonstrated that the field trials from 1992-2003 showed 10\% yield reduction of rice for every raise in one degree of minimum temperature (Peng et al., 2004). High temperature affects all stages of rice plant starting from germination, growth, development, reproduction and yield (Krishnan et al., 2011). The tiller number decreased by $10 \%$ when temperature rise from $29 / 21^{\circ} \mathrm{C}$ to $37 / 29^{\circ} \mathrm{C}$ (Manalo et al., 1994 ). The synchronism between the emergence of main stem and tiller and also mobilization of nutrients among tillers were affected by high temperature resulting in decreased yield as primary tillers are directly proportional to grain yield in rice (Yoshida, 1981).

Cold deserts are found in high, flat areas, called plateaus, or mountainous areas in temperate regions of the world. Cold deserts have hot summers but extremely cold winters. The Western Himalayan cold deserts have extremes of hot and cold climate combined with excessive dryness. Soil has light grey, poor in fertility and less water holding capacity. Therefore, these desert plants develop some physiological mechanisms like CAM (Crassulacean acid metabolism), modified leaf and also take the advantage of microbial endophytes to survive in hostile environment (Zhang and White, 2021).

The endophytes can colonize the plant tissue without causing any apparent harm and provide fitness under hostile environment. Endophytes can be cultured in-vitro and transfer to compatible secondary plants to obtain similar benefits (Redman et al., 2002 and Wang et al., 2021). Endophytes isolated from cold deserts seems to adapt wider range of temperature as cold desert has influenced by fluctuated temperature ranges from $-45^{\circ} \mathrm{C}$ in winter to $40^{\circ} \mathrm{C}$ in summer (Tewari and Kapoor, 2013). Therefore, we used in our study the endophytes isolated from the cold desert plants to understand induction of thermotolerance temperature sensitive rice variety IR-64.

\section{Materials And Methods}

\section{Screening for thermotolrance of endophytic isolates}

The fungal endophytes isolated from Artemisia and xerophytic plants of Western Himalayan cold desert and preserved at School of Ecology and Conservation Laboratory, University of Agricultural Sciences, Bangalore-560065. The 22 isolates were procured and rejuvenated on potato dextrose agar (PDA) for the present study. The endophytic isolates were screened for temperature tolerance. Isolates were cultured in PDA plates and incubated at different temperature $\left(28^{\circ} \mathrm{C}, 30^{\circ} \mathrm{C}, 32^{\circ} \mathrm{C}, 34^{\circ} \mathrm{C}, 36^{\circ} \mathrm{C}, 38^{\circ} \mathrm{C}\right.$ and $\left.40^{\circ} \mathrm{C}\right)$ for five days. Fungal growth was measured by radial diameter of colony on fifth day of incubation.

\section{Molecular identification of thermotolerant endophytic isolates}

The endophytic isolates of genomic DNA were extracted by Cetyltrimethylammonium bromide (CTAB) method (Vainio et al., 1998). The internal transcribed spacer (ITS) region of genomic DNA was amplified using universal primer ITS1-F (5区 TCCGTAGGTGAACCTGCGG 3ロ) and ITS4-R (5!

TCCTCCGCTTATTGATATGC 3区) by polymerase chain reaction (PCR). PCR amplification was performed using Master cycler (Eppendorf, Germany) with a 20 $\mu$ l reaction mixture that comprised $2 \mu \mathrm{l} 1 \mathrm{X}$ taq buffer with $\mathrm{MgCl}_{2}(1.5 \mathrm{mM}), 2 \mu \mathrm{l}$ dNTP's $(10 \mathrm{mM}), 0.5 \mu \mathrm{l}$ each primer (10pmol), $0.3 \mu \mathrm{l}$ Taq DNA polymerase (3U) and $1 \mu$ template DNA (100ng). The PCR was carried out with an initial denaturation at $94^{\circ} \mathrm{C}$ for $4 \mathrm{~min}$, followed by 35 cycles at $94^{\circ} \mathrm{C}$ for $30 \mathrm{~s}, 55^{\circ} \mathrm{C}$ for $1 \mathrm{~min}$ and $72^{\circ} \mathrm{C}$ for $30 \mathrm{~s}$, and a final extension at $72^{\circ} \mathrm{C}$ for $12 \mathrm{~min}$. The PCR amplified products were sequenced by SciGenome labs, Cochin, Kerala, India. The nucleotide sequences were queried in the NCBI GenBank database using a Basic Local Alignment Search Tool (BLAST). Sequences of each fungal species and corresponding reference sequences from GenBank were subjected to ClustalW analysis. The phylogenetic tree was constructed through maximum likelihood method and Tamura- Nei model, using MEGA X. The recognized sequences were placed in GenBank with accession number.

\section{Interaction of fungal endophytes with Rice under heat stress}

Evaluation of fungal endophytes on their ability to impart heat tolerance in rice (variety IR-64) was carried out in plant growth chamber at Indian Institute of Horticulture Research (ICAR-IIHR), Hesaraghatta, Bangalore. There were two sets of experiments. 1. Heat stress ( $45^{\circ} \mathrm{C}$ for $7 \mathrm{~h}$ per day for 10 days) and 2. Without heat stress (normal temperature conditions, $30 \pm 0.5^{\circ} \mathrm{C}$ ). Each set comprised with following treatments. 1. Control (uninoculated plants) 2.Ceriporia lacerate 3. Endomelanconiopsis endophytica and 4. Penicilium funiculosum. Rice seeds were surface sterilized using $3 \%$ sodium hypochlorite followed by 70 $\%$ alcohol. The surface sterilized seeds were repeatedly washed with sterile water and soaked for overnight. The pre-germinated seeds were sown in pots filled with soil and FYM (1:1w/w). Three seedlings per pot were maintained and grown for fifteen days. The thermotolerant endophytes were inoculated by stem prick method (Bhunjun et al., 2020) and allowed to colonize for 10 days. After colonization, set- 1 seedlings were exposed to heat (45 $\left.{ }^{\circ} \mathrm{C}\right)$ for 10 days in growth 
chamber. Observations for plant height, number of tillers, number of leaves, root volume, fresh and dry weight of roots were recorded after 10 days of heat exposure. Similarly, observations for plants grown under normal conditions (set-2) were recorded.

\section{Statistical Analysis}

The data generated during experimentation was analyzed by one-way analysis of variance and means were separated by Duncan's Multiple Range Test (DMRT) using the software XL STAT. The 3-D plot of stress tolerance index (STI) of biomass was constructed according to Fernandez (1992) model using iPASTIC online tool kit (https://manzik.com/ipastic/).

\section{Results}

\section{Screening and identification of thermotolerant fungal endophytes}

All endophytic isolates showed good growth up to $30^{\circ} \mathrm{C}$, beyond that there is gradual reduction in growth. This indicated that the optimum temperature of these isolates ranges from 28 to $30^{\circ} \mathrm{C}$. Three isolates viz., A2, A7 and X5 recorded tolerance level up to $40^{\circ} \mathrm{C}$ (Table 1). Hence, these isolates were selected for identification and further experiment.

Thermotolerant isolates were identified using ITS (Internal Transcribed Spacer) regions of rDNA and BLAST search. All the isolates such as A2, A7 and X5 showed 98\% similarity with Penicillium funiculosum strain C2-20, Ceriporia lacerate strain BHU MS1 and Endomelanconiopsis endophytica strain CR3 respectively (Fig.1a-1C). The isolates A2, A7 and X5 belongs to three different genera, namely Penicillium funiculosum, Ceriporia lacerate and Endomelanconiopsis endophytica and the obtained sequences were deposited in GenBank under the accession no. OM368442, MT899187 and MT900590 respectively (Table 2). The molecular identification was reconfirmed by their macro- and micro-morphological characteristics (Fig. 2). The colony of $P$. funiculosum had greyish green with funiculose texture on PDA media and examined biverticillate condiophore with subterminal branches and ellipsoidal conidia. In case of $C$. lacerate, white fluffy colonies was observed with aseptate hyphae. Initially colourless colony was observed in $E$. endophytica and later it become hyaline with shine black color and examined pycnidial conidiomata with ellipsoidal conidia.

\section{Effects of endophytes isolated from cold desert on imparting thermotolerance in rice}

The fungal endophytes inoculation significantly $(\mathrm{P}<0.01)$ improved all growth attributes of rice plants except plant height under both heat stress as well as normal conditions (Table 3 and 4). An endophyte $P$. funiculosum colonized plants found superior in increasing plant height, number of tillers and leaves, root volume, fresh and dry weight of shoot and root in normal growth condition. Whereas under stress condition, the $E$. endophytica and $P$. funiculosum colonized plants showed significantly $(P<0.01)$ higher shoot and root growth parameter compared to $C$. lacerate. The un-inoculated plants produced least growth of rice.

\section{Categories of treatments based on their performance in normal and stress conditions}

The treatments were divided into four categories based on Fernandez (1992) model using stress tolerance index of biomass. The treatment $E$. endophytica inoculated plants belongs to group A that indicates the production of higher biomass under the both conditions (normal and stress). The $P$. funiculosum and $C$. lacerate fall under group $B$ having maximum biomass only under normal growth condition. The uninoculated plants formed group $D$ produced least biomass under both the conditions (Fig. 3).

\section{Discussion}

The numerous studies have been conducted on improvement of crop growth under heat stress using thermotolerant endophytes isolated from harsh environment or wild plants. However, the use of cold desert thermotolerant endophytes were less explored therefore we have analysed the effect of cold desert endophytes on improvement of fitness of rice under heat stress. In present study, the isolates A2, A7 and X5 were observed to be heat tolerant and grown at the range from $28^{\circ} \mathrm{C}$ to $40^{\circ} \mathrm{C}$. This envisaged that these three isolates could sustain heat stress it might be the cold desert of Western Himalaya had extreme of hot climate $\left(40^{\circ} \mathrm{C}\right)$ during summer (Tewari and Kapoor, 2013). These endophytes were identified using ITS region of rDNA as $P$. funiculosum, $C$. lacerate and $E$. endophytica. The ITS region of rDNA sequences is widely used to examine phylogenetic positions or relationship of a species because this region are flanked by preserved segments (18S, $5.8 \mathrm{~S}$ and $28 \mathrm{~S}$ genes) which provide information about the phylogeny and the taxonomic level, since their evolution is slow and they are highly similar within different taxa (Ramesh et al., 2017).

High temperature is one of the most important environmental stresses which severely affect the rice growth by reducing the emergence of leaves and tillers resulting in decreased biomass. In the present study, significant higher tiller number was recorded when the plants inoculated with $E$. endophytica, which might positively influenced the new tillers under heat stress by reducing the effects of heat stress on tiller bud. This is in accordance with Vila-Aiub et al. (2005) who reported that Neotyphodium sp. infected rye grass produced more tillers than uninfected plants. The endophyte $P$. funiculosum inoculated plants showed highest number of leaves compared to other endophytes which resulted in increased fresh weight of shoot. Similarly Lolium perenne infected with Epichloe endophyte had significantly higher tillers number, dry weight, leaf length and wet weight under drought condition (Jajarmi et al., 2015)

The root system plays a vital role in adaptation of whole plant under heat stress (Huang et al., 2012). Significant improved in root growth was observed in endophytes colonized plants which lead to improved absorption of nutrients and water from soil, resulting in a more vigorous plant and helps to cope of heat stress. E. endophytica colonized plants found better in influencing the root growth compared to others. Our results are in agreement with Waqas et al., (2015) who demonstrated that Paecilomyces formosus LWL1 improved root biomass of rice under heat stress. Higher root to shoot ratio was found in plants inoculated with E. endophytica, which indicate that the endophyte could protect the root system. 
In conclusion, this investigation explored the possibility of using cold desert endophytes for mitigating the heat stress. The endophyte $E$. endophytica seems to be more effective in imparting heat stress tolerance in rice by improving the growth of shoot and root attributes (IR-64).

\section{Declarations}

\section{Acknowledgments}

Authors are grateful to Dr. Uma shaanker, School of Ecology and Conservation laboratory, UAS, GKVK, Bangalore for providing fungal cultures. APS thankful to the Department of Science and Technology (DST), GOI, New Delhi, for awarding INSPIRE fellowship (DST/INSPIRE Fellowship/2016/IF160469).

\section{References}

1. Baker, J.T., Allen, L.H., Boote, K.J. 1992. Temperature effects on rice at elevated CO2 concentration. J. Exp. Bot. 43:959-964. Baldani VD, Baldani JI and Döbereiner J (2000) Inoculation of rice plants with the endophytic diazotrophs Herbaspirillumseropedicae and Burkholderia spp. Biol. Fertil. Soils. 30: 485-491.

2. Bhunjun, C.S., Phillips, A.J.L., Jayawardena, R.S., Promputtha, I. and Hyde, K.D. 2020. Importance of Molecular Data to Identify Fungal Plant Pathogens and Guidelines for Pathogenicity Testing Based on Koch's Postulates. Pathogens. 10: 10-96.

3. Fernandez, G.C.J. 1992. Effective selection criteria for assessing plant stress tolerance. In: Proceedings of the international symposium on adaptation of vegetable and other food crops in temperature and water stress. Taiwan. pp. 257-270.

4. Huang, B., Rachmilevitch, S. and Xu, J. 2012. Root carbon and protein metabolism associated with heat tolerance. J. Exp. Bot. 63(9): $3455-3465$.

5. Jajarmi, V., Bihamta, M. R., Sabzalian, M. R., Majidi I. and Darvish, F., 2015, The role of endophytic fungi in drought resistance of Loliumperenne in Iran. Ecol. Environ. Conserv., 21: 437-445

6. Krishnan, P.B., Ramakrishnan, K., Reddy, R. and Reddy, V.R. 2011. High-Temperature Effects on Rice Growth, Yield, and Grain Quality. Advances in Agronomy. 87-209.

7. Manalo, P.A., Ingram, K.T., Pamplona, R.R. and Egeh, A.O. 1994. Atmospheric carbon dioxide and temperature effects on rice. Agric. Ecosyst. Environ. 51: 339-347.

8. Peng, S., Huang, J., Sheehy, J.E., Laza, R.C., Visperas, R.M., Zhong, X., et. al. 2004. Rice yields decline with higher night temperature from global warming. Proc Natl Acad SciUSA 101: 9971-9975.

9. Ramesh, V., Arivudainambi, U.S.E. and Rajendran, A. 2017. The molecular phylogeny and taxonomy of endophytic fungal species from the leaves of Vitexnegundo L. Studies inFungi. 2(1): 26-38.

10. Redman, R.S., Sheehan, K.B., Stout, R.G., Rodriguez, R.J. and Henson, J.M. 2002. Thermotolerance generated by plant/fungal symbiosis. Science. 298 (5598): 1581-1581.

11. Tewari, V.P. and Kapoor, K.S. 2013. Western Himalayan Cold Deserts: Biodiversity, Eco-Restoration, Ecological Concerns and Securities. Annals of Arid Zone 52(4): 223-230.

12. Vainio, E.J., Korhonen, K. and Hantula, J. 1998. Genetic variation in Phlebiopsisgigsntea as detected with random amplified microsatellite (RAMS) markers. Mycol. Res. 102: 187-192.

13. Vila-Aiub, M.M., Gundel, P.E. and Ghersa, C.M. 2005. Fungal endophyte infection changes growth attributes in Lolium multiflorum Lam. Austral. Ecol. 30(1): 49-57.

14. Wang, F., Zhang, R., Yuan, Z. and Chen, P. 2021. Biological prevention and control of pitaya fruit canker disease using endophytic fungi isolated from papaya. Arch Microbiol. 1-8

15. Waqas, M., Khan, A.L., Shahzad, U.I., Khan, A.R. and Lee, I.J. 2015. Mutualistic fungal endophytes produce phytohormones and organic acids that promote japonica rice plant growth under prolonged heat stress. J Zhejiang Univ-Sci B (Biomed \& Biotechnol) 16(12): 1011-1018.

16. Yoshida, S. 1981. Fundamentals of Rice Crop Science. International Rice Research Institute, Los Banos, Philippines.

17. Zhang, Q. and White, J.F. 2021. Bioprospecting Desert Plants for Endophytic and Biostimulant Microbes: A Strategy for Enhancing Agricultural Production in a Hotter, Drier Future. Biol. (Basel).10(10): 961.

\section{Tables}

Table 1. Effects of different temperatures on growth of the fungal colony (diameter in $\mathrm{cm}$ ) 


\begin{tabular}{|c|c|c|c|c|c|c|c|}
\hline \multirow[t]{2}{*}{ ophytic fungal isolates } & \multicolumn{7}{|c|}{ Temperature $\left({ }^{\circ} \mathrm{C}\right)$} \\
\hline & 28 & 30 & 32 & 34 & 36 & 38 & 40 \\
\hline$\overline{A 1}$ & $6.13 \pm 0.23$ & $5.80 \pm 0.1$ & $5.76 \pm 0.09$ & $2.73 \pm 0.12$ & $1.83 \pm 0.03$ & $0.6 \pm 0.05$ & - \\
\hline$\overline{\mathrm{A} 2}$ & $4.36 \pm 0.09$ & $5.67 \pm 0.09$ & $4.5 \pm 0.17$ & $3.46 \pm 0.12$ & $2.83 \pm 0.09$ & $1.80 \pm 0.06$ & $1.43 \pm 0.03$ \\
\hline A3 & $6.03 \pm 0.15$ & $5.20 \pm 0.12$ & $4.13 \pm 0.09$ & $2.80 \pm 0.06$ & $3.00 \pm 0.12$ & $0.73 \pm 0.03$ & - \\
\hline $\mathbf{A 4}$ & $4.50 \pm 0.06$ & $3.70 \pm 0.25$ & $1.73 \pm 0.03$ & - & - & - & - \\
\hline A5 & $5.37 \pm 0.09$ & $4.00 \pm 0.12$ & $2.90 \pm 0.06$ & $2.00 \pm 0.06$ & $1.32 \pm 0.15$ & - & - \\
\hline A6 & $3.76 \pm 0.09$ & $2.90 \pm 0.06$ & $1.86 \pm 0.09$ & $1.20 \pm 0.03$ & - & - & - \\
\hline A7 & $5.33 \pm 0.33$ & $4.03 \pm 0.09$ & $4.36 \pm 0.09$ & $3.80 \pm 0.12$ & $2.83 \pm 0.09$ & $2.03 \pm 0.20$ & $1.40 \pm 0.06$ \\
\hline A8 & $4.8 \pm 0.06$ & $3.03 \pm 0.03$ & $1.76 \pm 0.09$ & - & - & - & - \\
\hline A9 & $2.30 \pm 0.06$ & $1.90 \pm 0.06$ & $0.63 \pm 0.09$ & - & - & - & - \\
\hline A10 & $3.56 \pm 0.21$ & $2.73 \pm 0.15$ & $1.86 \pm 0.12$ & $1.56 \pm 0.21$ & $1.43 \pm 0.12$ & $0.86 \pm 0.06$ & - \\
\hline A11 & $4.03 \pm 0.12$ & $3.30 \pm 0.21$ & $2.50 \pm 0.06$ & $2.66 \pm 0.30$ & $1.30 \pm 0.12$ & $0.40 \pm 0.06$ & - \\
\hline A12 & $1.90 \pm 0.06$ & $2.36 \pm 0.15$ & $3.00 \pm 0.12$ & $3.93 \pm 0.03$ & $1.63 \pm 0.09$ & $0.76 \pm 0.09$ & - \\
\hline $\mathrm{X} 1$ & $3.50 \pm 0.17$ & $2.93 \pm 0.09$ & $2.26 \pm 0.09$ & $1.36 \pm 0.09$ & - & - & - \\
\hline $\mathrm{X} 2$ & $3.66 \pm 0.03$ & $2.40 \pm 0.06$ & $1.80 \pm 0.06$ & $1.33 \pm 0.09$ & - & - & - \\
\hline X3 & $5.96 \pm 0.09$ & $5.50 \pm 0.06$ & $5.00 \pm 0.06$ & $4.43 \pm 0.03$ & $1.43 \pm 0.07$ & - & - \\
\hline $\mathrm{X4}$ & $1.76 \pm 0.09$ & $1.26 \pm 0.07$ & - & - & - & - & - \\
\hline $\mathrm{X} 5$ & $8.76 \pm 0.03$ & $8.16 \pm 0.03$ & $8.66 \pm 0.09$ & $8.06 \pm 0.18$ & $3.46 \pm 0.09$ & $1.93 \pm 0.09$ & $1.13 \pm 0.06$ \\
\hline $\mathrm{X} 6$ & $3.96 \pm 0.09$ & $2.9 \pm 0.06$ & $1.86 \pm 0.09$ & $1.26 \pm 0.07$ & - & - & - \\
\hline X7 & $4.00 \pm 0.12$ & $2.93 \pm 0.09$ & $2.26 \pm 0.09$ & $1.26 \pm 0.03$ & - & - & - \\
\hline X8 & $3.93 \pm 0.09$ & $2.90 \pm 0.06$ & $1.63 \pm 0.09$ & - & - & - & - \\
\hline $\mathrm{X} 9$ & $1.9 \pm 0.06$ & $2.36 \pm 0.15$ & $3.00 \pm 0.12$ & $3.93 \pm 0.03$ & $1.63 \pm 0.09$ & $0.76 \pm 0.09$ & - \\
\hline $\mathrm{X} 10$ & $3.63 \pm 0.09$ & $3.30 \pm 0.21$ & $2.50 \pm 0.06$ & $2.66 \pm 0.30$ & $1.30 \pm 0.12$ & $0.40 \pm 0.06$ & - \\
\hline
\end{tabular}

Data shown above are the means of three replication with \pm standard error. A-Artemisia plant X-Xerophytic plant

Table 2. Molecular identification of thermotolerant fungal endophytes

\begin{tabular}{|c|c|c|c|c|c|c|c|c|}
\hline $\begin{array}{l}\text { Sl. } \\
\text { No. }\end{array}$ & Hosts & $\begin{array}{l}\text { Isolates } \\
\text { code }\end{array}$ & Closest match & $\begin{array}{c}\text { Sequence } \\
\text { length (bp) }\end{array}$ & $\begin{array}{l}\text { Query } \\
\text { coverage } \\
(\%)\end{array}$ & $\begin{array}{c}\text { Percent } \\
\text { identity (\%) }\end{array}$ & $\begin{array}{l}\text { Organisms } \\
\text { identified }\end{array}$ & $\begin{array}{c}\text { NCBI } \\
\text { Accession } \\
\text { no. }\end{array}$ \\
\hline 6 & Artimisia sp. & A2 & $\begin{array}{c}\text { Penicillium } \\
\text { funiculosum strain C2-20 }\end{array}$ & 654 & 98 & 99 & $\begin{array}{l}\text { Penicillium } \\
\text { funiculosum }\end{array}$ & OM368442 \\
\hline 7 & Artimisia sp. & A7 & $\begin{array}{c}\text { Ceriporia lacerate strain } \\
\text { BHU-MS1 }\end{array}$ & 479 & 96 & 98 & Ceriporia lacerate & MT899187 \\
\hline 8 & $\begin{array}{l}\text { Xerophytic } \\
\text { plant }\end{array}$ & $\mathrm{X} 5$ & $\begin{array}{c}\text { Endomelanconiopsis } \\
\text { endophytica strain } 5345\end{array}$ & 473 & 98 & 98 & $\begin{array}{c}\text { Endomelanconiopsis } \\
\text { endophytica }\end{array}$ & MT900590 \\
\hline
\end{tabular}

Table 3. Influence of fungal endophytes on shoot attributes of rice under stress [S] and without stress [WS]

\begin{tabular}{|c|c|c|c|c|c|c|c|c|c|}
\hline \multirow[t]{2}{*}{ Treatments } & \multicolumn{2}{|c|}{ Plant height $(\mathrm{cm})$} & \multicolumn{2}{|c|}{ No. of Tillers (/3plant) } & \multicolumn{2}{|c|}{ No. of Leaves (/3plant) } & \multicolumn{2}{|c|}{$\begin{array}{c}\text { Fresh wt. shoot } \\
\text { (g/3plant) }\end{array}$} & \multirow{2}{*}{$\begin{array}{r}\text { Dry wt. s } \\
\text { WS }\end{array}$} \\
\hline & WS & $\mathrm{S}$ & WS & $\mathrm{S}$ & $\overline{\text { WS }}$ & $\mathrm{S}$ & WS & $\mathrm{S}$ & \\
\hline Control & $33.53 \pm 0.72^{b}$ & $32.76 \pm 0.27^{a}$ & $8.50 \pm 0.20^{\mathrm{c}}$ & $6.50 \pm 0.20^{b}$ & $36.50 \pm 0.61^{d}$ & $28.00 \pm 0.41^{\mathrm{c}}$ & $5.95 \pm 0.07^{d}$ & $3.13 \pm 0.02^{\mathrm{c}}$ & $1.54 \pm 0.0$ \\
\hline C. lacerata & $35.51 \pm 1.17^{\mathrm{ab}}$ & $32.62 \pm 0.59^{a}$ & $10.50 \pm 0.20^{b}$ & $6.00 \pm 0.00^{c}$ & $40.00 \pm 0.00^{c}$ & $27.50 \pm 0.20^{c}$ & $7.92 \pm 0.08^{c}$ & $3.77 \pm 0.07^{b}$ & $2.33 \pm 0.0$ \\
\hline $\begin{array}{c}\text { E. } \\
\text { endophytica }\end{array}$ & $36.96 \pm 0.53^{a}$ & $32.01 \pm 0.45^{\mathrm{a}}$ & $11.00 \pm 0.00^{\mathrm{b}}$ & $7.00 \pm 0.00^{\mathrm{a}}$ & $45.00 \pm 0.12^{b}$ & $37.00 \pm 0.41^{b}$ & $8.89 \pm 0.05^{b}$ & $3.83 \pm 0.00^{b}$ & $2.26 \pm 0.0$ \\
\hline $\begin{array}{c}P . \\
\text { funiculosum }\end{array}$ & $36.62 \pm 0.19^{a}$ & $32.79 \pm 0.76^{a}$ & $14.50 \pm 0.20^{\mathrm{a}}$ & $6.50 \pm 0.20^{b}$ & $55.50 \pm 0.20^{\mathrm{a}}$ & $39.00 \pm 0.41^{\mathrm{a}}$ & $10.36 \pm 0.08^{a}$ & $4.21 \pm 0.05^{\mathrm{a}}$ & $2.64 \pm 0.0$ \\
\hline$\left(F_{3,12}\right)$ & 3.31 & 0.432 & 199.33 & 8.00 & 142.78 & 263.85 & 660.86 & 107.57 & 184.85 \\
\hline$P$ & 0.028 & 0.734 & $<0.0001$ & 0.003 & $<0.0001$ & $<0.0001$ & $<0.0001$ & $<0.0001$ & $<0.000$ \\
\hline
\end{tabular}

\pm indicates standard error of mean $(\mathrm{n}=4)$; the dissimilar letters indicate significant difference at $P<0.05$ by using Duncan's Multiple Range Test. 
Table 4. Influence of fungal endophytes on root traits and total biomass of rice under stress [S] and without stress [WS]

\begin{tabular}{|c|c|c|c|c|c|c|c|c|c|}
\hline \multirow[t]{2}{*}{ Treatments } & \multicolumn{2}{|c|}{$\begin{array}{l}\text { Root volume } \\
\left(\mathrm{cm}^{3} / 3 \text { plant) }\right.\end{array}$} & \multicolumn{2}{|c|}{ Fresh wt. root (g/3plant) } & \multicolumn{2}{|c|}{ Dry wt. root (g/3plant) } & \multicolumn{2}{|c|}{ Root:Shoot } & \multirow{2}{*}{$\begin{array}{c}\text { Biomass (! } \\
\text { WS }\end{array}$} \\
\hline & WS & $\mathrm{S}$ & WS & $\mathrm{S}$ & WS & $\bar{S}$ & WS & $\mathrm{S}$ & \\
\hline Control & $12.00 \pm 0.00^{b}$ & $3.00 \pm 0.00^{\mathrm{c}}$ & $7.88 \pm 0.16^{\mathrm{c}}$ & $2.23 \pm 0.05^{\mathrm{d}}$ & $1.38 \pm 0.05^{\mathrm{bc}}$ & $0.29 \pm 0.01^{\mathrm{d}}$ & $0.89 \pm 0.02^{\mathrm{a}}$ & $0.34 \pm 0.01^{\mathrm{c}}$ & $2.92 \pm 0.06^{\mathrm{c}}$ \\
\hline C. lacerata & $6.50 \pm 0.00^{\mathrm{d}}$ & $3.95 \pm 0.10^{\mathrm{b}}$ & $7.76 \pm 0.55^{\mathrm{c}}$ & $3.45 \pm 0.00^{c}$ & $1.27 \pm 0.06^{\mathrm{c}}$ & $0.35 \pm 0.01^{\mathrm{c}}$ & $0.55 \pm 0.02^{\mathrm{d}}$ & $0.39 \pm 0.01^{b}$ & $3.60 \pm 0.12^{\mathrm{b}}$ \\
\hline $\begin{array}{c}E . \\
\text { endophytica }\end{array}$ & $11.50 \pm 0.20^{\mathrm{c}}$ & $4.25 \pm 0.02^{\mathrm{a}}$ & $9.88 \pm 0.15^{\mathrm{b}}$ & $4.03 \pm 0.06^{\mathrm{a}}$ & $1.46 \pm 0.02^{\mathrm{b}}$ & $0.47 \pm 0.02^{\mathrm{a}}$ & $0.64 \pm 0.01^{\mathrm{c}}$ & $0.44 \pm 0.02^{\mathrm{a}}$ & $3.72 \pm 0.03^{b}$ \\
\hline $\begin{array}{c}P . \\
\text { funiculosum }\end{array}$ & $13.90 \pm 0.04^{\mathrm{a}}$ & $4.00 \pm 0.00^{\mathrm{b}}$ & $12.73 \pm 0.07^{\mathrm{a}}$ & $3.64 \pm 0.00^{b}$ & $1.98 \pm 0.04^{\mathrm{a}}$ & $0.39 \pm 0.01^{b}$ & $0.75 \pm 0.01^{b}$ & $0.36 \pm 0.01^{\mathrm{bc}}$ & $4.61 \pm 0.07^{\mathrm{a}}$ \\
\hline$\left(F_{3,12}\right)$ & 920.23 & 111.39 & 59.85 & 445.68 & 46.17 & 56.97 & 101.74 & 15.35 & 83.62 \\
\hline$P$ & $<0.0001$ & $<0.0001$ & $<0.0001$ & $<0.0001$ & $<0.0001$ & $<0.0001$ & $<0.0001$ & 0.000 & $<0.0001$ \\
\hline
\end{tabular}

\pm indicates standard error of mean $(\mathrm{n}=4)$; the dissimilar letters indicate significant difference at $P<0.05$ by using Duncan’s Multiple Range Test.

\section{Figures}

$\mathbf{a}$

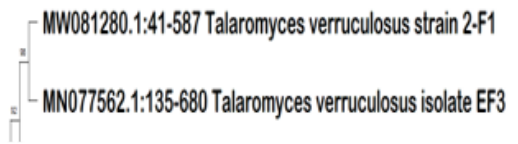

b

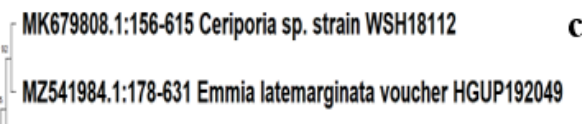

C

MH835348.1:54.518 Endomelanconiopsis sp. isolate ESEF5

MH862651.1:91.560 Endomelanconiodsis microsoora strain CBS 353.97

\section{Figure 1}

MaximumLikelihood tree of the identified fungal endophytes (a) Penicillium funiculosum isolate A2) (b) Ceriporia lacerate isolate A7 and (c) Endomelanconiopsis endophytica isolate X5 and their closest ITS rDNA matches from the GenBank. The phylogenetic tree was constructed with bootstrap value of 500 replicates. Number at the node indicates the bootstrap value. 

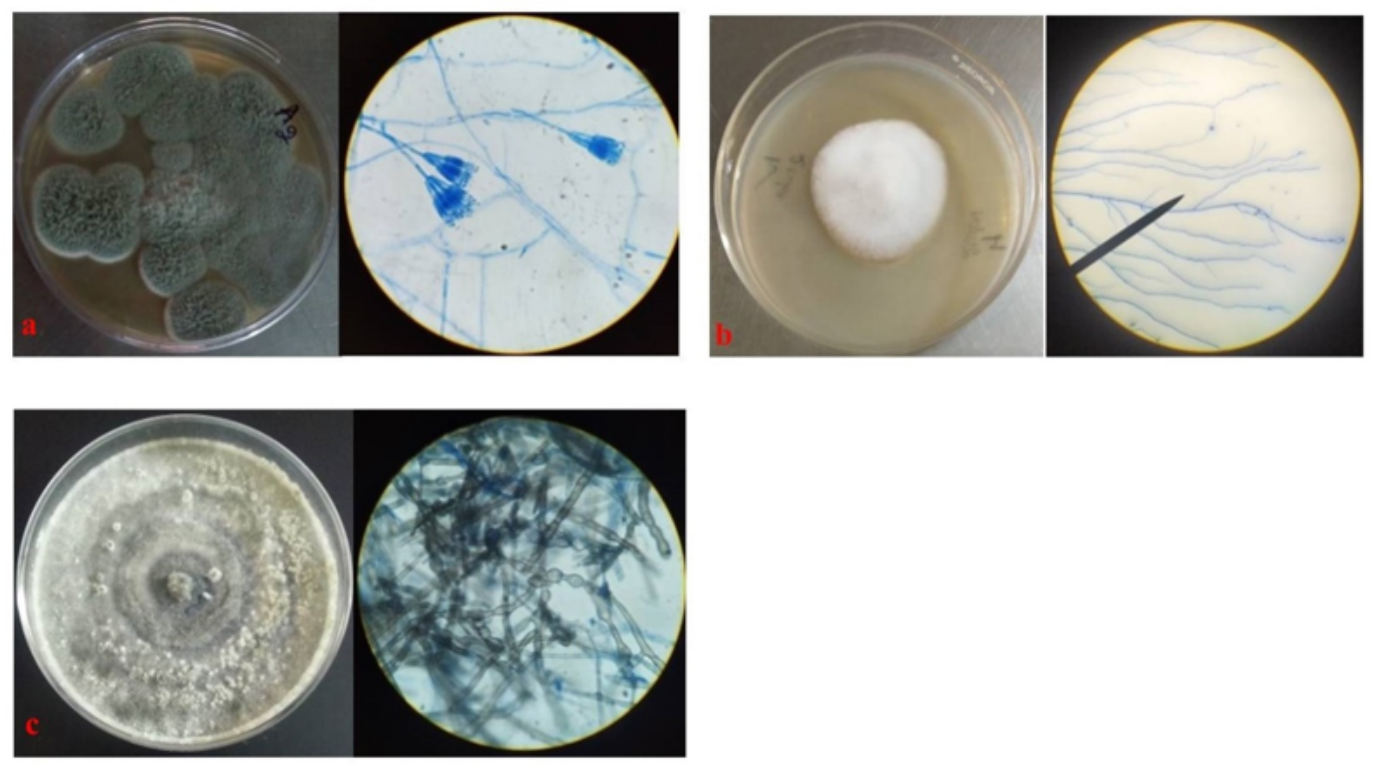

\section{Figure 2}

Fungal colony grown on PDA medium and their fruiting body under microscope (lactophenol cotton blue stain) (a) Penicilium funiculosum isolate A2 colony and their conidiophore (b) Ceriporia lacerate isolate A7 colony and their aseptate mycelia colony and their hyphae (c) Endomelanconiopsis endophytica isolate $\mathrm{X} 5$ and their mycelia.

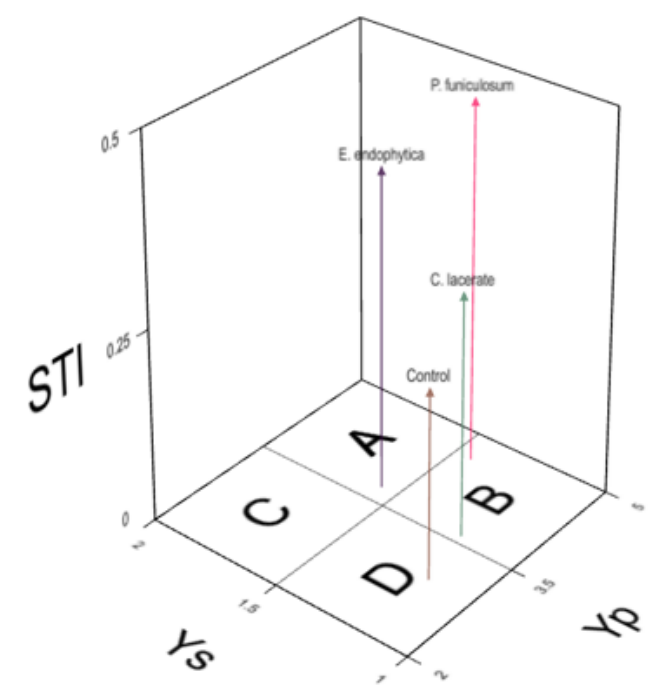

\begin{tabular}{cccc}
\hline Treatments & Yp & Ys & STI \\
\hline Control & 2.92 & 1.16 & 0.25 \\
C. lacerate & 3.6 & 1.22 & 0.32 \\
E. endophytica & 3.72 & 1.56 & 0.42 \\
P. funiculosum & 4.61 & 1.44 & 0.48 \\
\hline
\end{tabular}

\section{Figure 3}

Three dimentional plot based on Fernandez (1992) model using stress tolerance index (STI) of biomass. Yp: Biomass under normal growth condition Ys: Biomass under heat stress. 